\title{
'I WOULDN'T DO ANYTHING DIFFERENTLY ... ALTHOUGH I WON'T LET MY CHILD GO IN THAT DIRECTION'- SUCCESSFUL HUNGARIAN OLYMPIANS' UNDERSTANDINGS AND EXPERIENCES AT THE CLOSE OF ELITE SPORT CAREERS
}

\author{
„NEM CSINÁLNÉK SEMMIT MÁSKÉNT... AZÉRT AZ ÉN GYEREKEM \\ NEHOGY EBBE AZ IRÁNYBA MENJEN" - SIKERES MAGYAR \\ OLIMPIKONOK TAPASZTALATAI, ÉLMÉNYEI A HIVATÁSOS \\ SPORTKARRIER LEZÁRÁSÁT KÖVETŐEN
}

Whilst the relationship between sport-related success and its effect on the identity of athletes has been acknowledged, less attention has been paid to understanding this relationship from the perspective of the individual. Elite sport follows the logic of individualism, competitiveness, and productivity, while elite athlete performance is depicted as being a remedy for society's ills by empowering control over health and serving as a good example for future generations. This dualism is reflected in the viewpoints of elite athletes: in their experiences, reflections, and memories. The aim of this paper is to formally examine through Hungarian elite athletes' experiences how elite sport is related to components of the athletic identity and their potential impact on individual sustainability. Results show (1) how essential the role of coaching is in elite athletes' careers, (2) how sport is seen as a protective shield, indicating the importance of life-long career planning, and (3) that there is cognitive dissonance regarding the identity of elite athletes.

Keywords: elite athletes, identity, individual sustainability, phenomenology, sport

Miközben a sportsikerek személyes identitásra gyakorolt hatása széles körben ismert, kevesebb figyelem terelődik arra, hogyan látja ezt az egyén, sportolói perspektívából. A hivatásos sport a verseny, az individualizmus és a hatékonyság logikáját követve elüzletiesedik, míg a sportolói csúcsteljesítményre gyakran a társadalmi bajok gyógyírjaként tekintünk: mert követendő példát mutat a jövő generációi számára, és felvértez egészségünk megőrzésére. Ez a kettősség tükröződik az élsportolók látásmódjában is: tapasztalataikban, reflexióikban és emlékeikben. A kutatás célja, hogy a sportolók tapasztalatain keresztül elemezze hogyan határozza meg a hivatásos sport a sportolói identitást, és annak az egyéni fenntarthatóságra gyakorolt hatását. Az eredmények azt mutatják, hogy (1) az edző szerepe kulcsfontosságú a hivatásos sportoló harmonikus karrierjéhez, (2) a sport egyfajta védőburok, ahol fontos az életre szóló karriertervezés és (3) a hivatásos sportolói identitást kognitív disszonancia jellemzi.

Kulcsszavak: egyéni fenntarthatóság, fenomenológia, hivatásos sportoló, identitás, sport

\section{Funding/Finanszírozás:}

The author did not receive any grant or institutional support in relation with the preparation of the study.

A szerző a tanulmány elkészítésével összefüggésben nem részesült pályázati vagy intézményi támogatásban.

\section{Acknowledgments/Köszönetnyilvánítás:}

The author would like to thank the five retired elite athletes for their engagement with this project. Without their enthusiasm and willingness to openly share their experiences, this research would not have been possible. The author thank Simon Milton for English-language proofreading and Tamás Kocsis for mentoring the research process.

A szerző köszönetet mond az öt visszavonult élsportolónak a projektben való részvételükért. Lelkesedésük és hajlandóságuk nélkül, hogy nyíltan megosszák tapasztalataikat, e kutatás nem lett volna lehetséges. A szerző köszönetet mond Simon Miltonnak az angol nyelvű lektorálásért és Kocsis Tamásnak a kutatási folyamat mentorálásáért.

\section{Author/Szerző:}

Attila Szathmári, assistant lecturer, Corvinus University of Budapest, (attila.szathmari@uni-corvinus.hu)

This article was received: 21. 09. 2020, revised: 13. 02. 2021, accepted: 17. 02. 2021.

A cikk beérkezett: 2020. 09. 21-én, javítva: 2021. 02. 13-án, elfogadva: 2021. 02. 17-én. 
A growing body of research has shown that elite athletes -i.e. those seen as successful by society - experience their careers differently as individuals. There is academic agreement that elite sport is a risky profession. The competitive logic that drives athletes to continuously aspire for high-level performance is associated with risk-taking and a disregard for health and well-being (Overbye, 2018).

This dualism has existed since elite sports became a business - a fairly recent phenomenon compared to the development of the rest of the economy, since sports professionalism and its commercialization only started within the last four decades (András, 2003; András et al., 2019; Dénes \& Misovitz, 1994; Szathmári \& Kocsis, 2020). The logic of elite sport is characteristic of the capitalist society that created it. Elite sport is the product of a growth-based society (Harangozó, Csutora \& Kocsis, 2018; Kerekes, Marjainé \& Kocsis, 2018; Kocsis, 2018), with its attendant subsystem and ideological support. Organized according to the logic of productivity, efficiency, evaluation, comparison, hierarchy, etc., elite sport reflects the conditions of society and makes its pitfalls even more visible (Liegey, Madelaine, Ondet \& Veillot, 2013).

Due to its system logic and risky consequences, some sports scientists have turned to identity-related concepts to challenge this dualism and elaborate whether and how elite sport might be individually sustainable (Dohlsten, Barker-Ruchti \& Lindgren, 2020). Sustainability can mean various things, and individuals may weigh different aspects of the latter concept in slightly different ways (Király et al., 2013). Researchers have claimed that it is rather complex and difficult for sport to meet the requirements of sustainability, as this would involve athletes, coaches, associations, organizers of sporting events, decision makers, representatives of the economic ecosystem, and sports-related social organizations, too - insofar as sustainability is based on long-term thinking and forward planning, and a rejection of short-term alternatives in order to achieve long-term goals (Dingle \& Mallen, 2020). This means, on the one hand, promoting the ecological aspects of sustainability - making sports green -, as well as fostering economic sustainability, legacy and profitability (Preuss, 2019). Last but not least, continuity in sports in the form of youth education and career planning could be also a part of this (Bohó et al., 2015; Szathmári, 2017). Yarmoliuk (2019) differentiated between environmental, social, and economic aspects in decision-making processes concerning sports sustainability. Researchers suggest that sustainability represents "a condition or set of conditions whereby human and natural systems can continue indefinitely in a state of mutual well-being, security, and survival" (Jones, Selby \& Sterling, 2010, p. 19).

While security and survival have become increasingly important topics for humankind, surprisingly few researchers have so far tried to build a concept of individual sustainability around elite sports. Lindsey (2008) defines individual sustainability as a longer-term shift in personal identity, ability, and/or attitude through development in relation to participation in sports. Loland (2006) emphasizes the relevance of human-centered perspectives and conducting elite sports in a way that can increase mutual well-being and respect. Kim et al., (2019) argue that we should create positive organizational practices to ensure the mental health of sports-related employees.

Earlier research focused on the psychological aspects of sport. In terms of the early burnout of athletes, Coakley (1992) examined whether we should talk about a social problem or individual mistakes. Finally, it has come to light that there is a flaw in social organizations, and their transformation is inevitable. Athletes' difficulty in bringing professional careers to a close has also emerged as an issue. In terms of success, Fletcher and Sarkar (2012) and Lundqvist (2011) analyzed the stress tolerance of Olympic champions in terms of individual sustainability.

While the researchers suggest that the demands and resources of careers in elite sport limit their career sustainability as elite athletes, they also reveal that a short-term career in sport does not prevent longer-term sustainability in other sphere. An increasing number of jobs/careers are becoming unsustainable due to high employer- and contextual demands, occupational stress, burnout, and lack of work-life balance (Richardson \& McKenna, 2020). The physical, psychological, and emotional demands of a career in elite sport often end in burnout and chronic levels of stress and injury that lead to the end of athletes' careers (Thelwell, Weston \& Greenless, 2007). This claim also supports those of other scholars who have argued that whereas some demands can be challenging, they are not inherently detrimental to work experience and to achieving short- and long-term goals and developing individual sustainability (Crawford, LePine \& Rich, 2010). Richardson and McKenna (2020) argue that, although the demand for a high level of performance may limit individual sustainability in elite sport, this should not be inherently problematic and may be something that can be "managed away." However, doing so may negatively impact athletes' motivation to participate, and hence subsequent performance.

In our exposition, individual sustainability is revealed by a focus on athletes as human beings and on personal needs. These traits allude to elite sport stakeholders' interest in building trust, honor, and diversity, which elements may make elite sports more sustainable (Annerstedt \& Lindgren, 2014; Barker-Ruchti, Rynne, Lee \& Barker, 2014; Szathmári, 2017). Lawson (2005) meticulously researched the relationship between sustainability and elite sport and concluded that elite sport's sustainability - due to its inherent logic - is fragile. This fragility is closely connected to the identity formation of athletes. Athletes who can restructure and preserve their identities prior to finishing their athletic careers might be better able to cope with the loss of the latter than those who maintain a strong commitment to their identities as athletes until their careers end, or even subsequently. It may be that those athletes who engage in self-preservation by controlling their investment into their athletic identity are also those who can more effectively steer their career transitions (Lally, 2007).

Athletes' identities incorporate the cognitive, affective, behavioral, and social aspects associated with their 
roles (Brewer, Van Raalte \& Linder, 1993). "Like all role identities, an athlete's identity is developed through the process of constructing and interpreting meanings within various social interactions. In this sense, athletes use socially constructed norms, values and beliefs associated with the sporting role to help understand the world around them" (Ryan, 2018, p. 1). Thus, understanding the identity component of athletes is a vital task when investigating the experiences of athletes, and research into identity in relation to individual sustainability in elite sport may offer insight into this specific parameter (Cosh, LeCouteur, Crabb \& Kettler, 2013).

While an individual's identity can consist of various dimensions, it is probable that one of these will become a dominant lens through which the others are viewed (Lally, 2007). Ideas about identity formation can thus contribute to understanding how sustainable elite sport can be expanded. Thus, the aim of this paper is to reveal athletes' needs and concerns regarding sustainable elite sport. Specifically, we aim to answer the following research question: What aspects of identity-construction influence the identities and individual sustainability of elite athletes? We try to elaborate how the sample athletes make sense of their elite sports careers, including what they see as important factors in relation to their success, and what they see as problems. In this sense, we seek to understand individual sustainability in sports as the product of the correspondence between the demands of an elite sport system and the individual athlete's personal needs and potential (Schubring \& Thiel, 2014).

\section{Materials and methods}

\section{Procedure}

The purpose of our research was to understand which elements of the non-growth paradigm in sport can be nudged to make sport a more sustainable economic activity. The basis is in-depth interviews with elite athletes that were examined using interpretative phenomenological analysis (IPA). (We also created a questionnaire with 23 statements to quantitatively reveal and help understand related issues with the help of sample groups in Hungary (Szathmári \& Kocsis, 2020)). IPA is a qualitative research method that is increasingly used, primarily in psychology. The basics of IPA are related to phenomenology and hermeneutics, which emphasize that individuals' experiences can only be interpreted in context. The IPA-based approach allows the researcher to view a specific experience from an "insider perspective," treating the researcher as an expert. The method seeks to identify and understand the experience as much as possible, and to understand how the person involved in the study interpreted it (Gelei, 2006; Kassai, Pintér \& Rácz, 2017). The aim of IPA research is thus to explore personal, lived experiences with phenomena, such as - in our case - athletes' career experiences (Smith, 2011). Qualitative research can help with understanding customers' / consumers' experiences and evaluations of a particular service (Fett, Bruns \& Lischka-Wittmann, 2009; Mitev, 2012). IPA is, therefore, an interpretative, hermeneutical method that can appear at several levels in the research process.

\section{Participants}

Targeted sampling was used. The five athletes we interviewed gave us access to a specific phenomenon that represented a "perspective" rather than a population. Following the recommendations of Smith et al. (2009), a state of homogeneity can be identified. Regarding the experiences of athletes, homogeneity should be present in the sense of the athlete's basic experiences and transitions, and the time spent on professional sporting activities. Accordingly, the main characteristics of the sample members' sporting experiences were similar in terms of individual/ team sports, popularity, domestic/international success, Olympic embeddedness, supporting system, and in how much time they had been inactive at the time of the interview. During the interview lead-up process, we identified five professional athletes whose selection process we considered homogeneous according to the criteria detailed below. One of the criteria was the sport itself - namely, interviews were restricted to athletes who had competed in individual sports (e.g. swimming or athletics). This was necessary because, according to Baker, Yardley and Coté (2003), team sportsmen's experiences apparently differ in terms of the effects of success/failure, expectations, and other psychological factors.

Another important criterion is the outcome of professional careers: in terms of measurement, our athletes had been awarded national championship titles, were internationally ranked, had participated in the Olympics, and can be identified as elite athletes. Also, the role of the time-horizon was considered an important criterion: we included athletes whose professional careers had finished some years ago, but who had formerly competed for more than a decade, so they had a reasonable distance from and some insight into this phase of their lives. The former professional athletes had not entirely ended their sport-related activities; in some form, they were still connected with the system. Based on their own experiences, Larkin, Eatough and Osborn (2011) suggest using a sample of three to six people. This is suitable for describing similarities and differences between individual cases.

Sample selection was based on Miles and Hubermann's (1994) classification that employs intensity-based criteria and comparable sampling techniques. The essence of the former is investigating information-rich cases. The research question is always open, is focused on exploration (not explanation), on process (not result), and aims at reporting (not identifying causes or consequences). The research question should also involve a special context (not, for example, a comparison of contexts). At the beginning of the research, we formulated a two-level research question (a first-level research question was followed by a second-level research question that could be theoretically grounded) (Somogyi et al., 2018). Our main research question was "What aspects of identity-construction influence the identities and individual sustainability of elite athletes?" 
Contact was based on pre-established relationships. This ensured that all the above-mentioned "intensity criteria" were met. Interviews were documented in a friendly environment known to the athletes. This prior contact ensured an open and frank atmosphere, and increased the chance that subjects could boldly express themselves.

\section{Data collection}

We implemented a semi-structured interview with each participant. Semi-structured interviews were used because the method permits the researcher's questions to guide the interview process while simultaneously allowing topics identified by the participants to be elaborated upon via probing (Rubin \& Rubin, 2012). Furthermore, with the use of non-numerical data this line of research helps explore and describe the "quality" and "nature" of how people behave, experience, and understand, and thus helps link people's actions to their beliefs (Brown, 2005). A semi-structured interview process was applied that incorporated the results of former questionnaire survey. Inquiring about the phenomenon we wanted to investigate (including experiences of injury, failure, or success) during the interviews allowed the identity of the interviewees to be evaluated in the context of the given experience.

Interviews were documented in 2015, each lasting between 60 and 90 minutes. Prior to these, participants were oriented about the object of the research and gave their informed consent. Recordings were made which were later destroyed. Documentation were transcribed and major nuncupative elements were labelled (such as chuckling and meaningful silences) and noted down.

\section{Data analysis}

In perusing the interview transcripts - so-called immersion in the data - the researcher "takes on the interviewee's viewpoint" (Pietkiewicz \& Smith, 2014) and makes the transcript better through analysing, explaining, interpreting and conceptualizing using free content analysis (Smith, Flowers \& Larkin, 2009). Conceptual commentary is "torn" from the direct text and is utilized to originate an understanding of the person on a more holistic level. It is characterized by the entire dialogue: the "dialogue" between the preliminary knowledge of the researcher, and an ongoing understanding of the interviewee's experiences.

The next step was the creation of emerging themes (Pietkiewicz \& Smith, 2014) by exploring all the interviews from a different perspective to that of the participants. In this, more emphasis was placed on the researcher's organizing and interpretative role. While creating a "new body" of outcomes, the themes continuously develop. A topic may become an emerging issue when it arises in at least half of the interviews (Smith, Flowers \& Larkin, 2009), and these topics should be written down in the transcript. In implementing this method, the researcher can incorporate psychological constructs into the process of interpretation.

\section{Results}

In the following sections, we explore the narrative types associated with identity construction through the selection of the latter experiences. Comparing the situation of athletes in sport to the situation with the environment, and examining the boundaries thereof, we must then look at what is socially desirable. Efficiency gains in the short term - or performance-related results in Hungarian sports - may not support human individual sustainability in the long term. In addition to physical and psychological factors, sport is also part of the human environment.

Coding of the first interview indicated that emotional affection was emphasized - athletes talked about coaches, parents, and age groups using several motifs ("desire," "love," "shield") that were analogous to the terms used in a relationship. Mention of these relationships occurred frequently in all interviews, so they may be considered distinct topics. Experience related to the attitude to training and fierce competition was also crucial (Figure 1).

Thereafter, we sought to identify the connections (such as chronological links) between the emerging themes and those overarching topics that could cover several subtopics. By using quotes from the interview transcripts and trying to reveal the patterns and groups of topics among the interviews, further interpretation of unfolding themes - called "master themes" - can be developed (Smith,

Exploratory themes that emerged during the coding process

Figure 1.

\begin{tabular}{|c|c|c|}
\hline PARENTS' ROLE & DESIRE & MENTAL/PHYSICAL HEALTH \\
\hline $\begin{array}{l}\text { you are your own person } \\
\text { there is no fight } \\
\text { familiy pressure --> study }\end{array}$ & $\begin{array}{c}\text { sport as love } \\
\text { coaching for love --> crazy } \\
\text { easier way vs. learning }\end{array}$ & $\begin{array}{c}\text { always pain } \\
\text { coach physical --> psychologist mental } \\
\text { enormous load --> hit back }\end{array}$ \\
\hline TRAINING & COACHES' ROLE & ABROAD \\
\hline $\begin{array}{c}\text { monotonous, hideous } \\
\text { playfulness <---> get results } \\
\text { no training --> still success }\end{array}$ & $\begin{array}{c}\text { luck, responsibility } \\
\text { no private life - after own's head } \\
\text { no killing-noticed-was built up }\end{array}$ & $\begin{array}{c}\text { horizon } \\
\text { scholarships } \\
\text { money, better facilities }\end{array}$ \\
\hline COMPETITION & VISION & AGE GROUP RELATION \\
\hline $\begin{array}{c}\text { injustice } \\
\text { happiness } \\
\text { eternal pain }\end{array}$ & $\begin{array}{c}\text { sport as protective cover } \\
\text { closed world: grime ---> cleaner, easier } \\
\text { black hole, vacuum }\end{array}$ & $\begin{array}{l}\text { trust only yourself <--> society } \\
\text { embarassing not to study } \\
\text { marriage, children later }\end{array}$ \\
\hline & $\begin{array}{l}\text { IDENTITY: WHO HAVE I BECOME? } \\
\text { never give up } \\
\text { tomorrow will be better } \\
\text { start at the bottom } \\
\text { role model, positive personality traits }\end{array}$ & \\
\hline
\end{tabular}


Flowers \& Larkin, 2009). During the analysis, the researcher interprets how the interviewee has interpreted their experience; this dual interpretation is a process of "double interpretation" wherein the second, scientifically and systematically performed interpretative work of the researcher can be considered a part of the reflective phenomenological attitude of IPA - as opposed to interviewees "naturally adjusted" pre-reflective observations, using Husserl's expressions (Smith et al., 2009).

\section{Primary and secondary themes}

a. The "central role of coaching": Closely associated with other emerging themes (parents, training, competition, and desire). The role of coaches (as part of a supporting system) is remarkable in terms of the original discovery of the athletes ("seeing something in me"), managing them properly ("not killing me") and long-term planning ("built up"). We identified motifs associated with long-term planning (athlete-coach-sport), athletes who face "burn-out," and other factors. "I was lucky with my coach as he did not burn me out in the drive to be successful; I was systematically built up to be good."

Primary and secondary themes identified and unfolded during the IPA process

Figure 2.

\begin{tabular}{|c|c|c|c|c|c|}
\hline \multicolumn{2}{|c|}{ Role of coaching } & \multicolumn{2}{|c|}{ Protective cover } & \multicolumn{2}{|c|}{ Social connectedness } \\
\hline Gains & Lack of... & Age-group & Problems & $\begin{array}{c}\text { Cognitive } \\
\text { dissonance }\end{array}$ & Child-like values \\
\hline $\begin{array}{l}\text { Appreciation, } \\
\text { relationship, } \\
\text { coach, emotions, } \\
\text { love }\end{array}$ & $\begin{array}{c}\text { Concept, working } \\
\text { system, lifelong } \\
\text { program, human } \\
\text { focus, } \\
\text { appreciation, long- } \\
\text { term perspective }\end{array}$ & $\begin{array}{c}\text { Privileges, } \\
\text { comparison, exit, } \\
\text { integration, } \\
\text { otherness }\end{array}$ & $\begin{array}{l}\text { Mentality, health, } \\
\text { age group, human } \\
\text { relationships, } \\
\text { transition }\end{array}$ & Belief, values & Motif, playfulness \\
\hline $\begin{array}{l}\text { It was the } \\
\text { expectation of the } \\
\text { [trainers at the] } \\
\text { swimming pool } \\
\text { that educational } \\
\text { studies would } \\
\text { continue. }\end{array}$ & $\begin{array}{c}\text {...these days } \\
\text { people - who do } \\
\text { something terrible, } \\
\text { worthless - gets } \\
\text { into the focus of } \\
\text { society.' }\end{array}$ & $\begin{array}{c}\text { 'Those of my age } \\
\text { group got married } \\
\text { earlier and had } \\
\text { babies earlier. } \\
\text { There is no healthy } \\
\text { golden mean, only } \\
\text { extremes.' }\end{array}$ & $\begin{array}{l}\text { Ask anyone at the } \\
\text { top! Sport is not } \\
\text { healthy anymore.' }\end{array}$ & $\begin{array}{c}\text { 'I wouldn't do } \\
\text { anything } \\
\text { differently ... } \\
\text { although I won't } \\
\text { let my child go in } \\
\text { that direction.' }\end{array}$ & $\begin{array}{l}\text { 'Participating in } \\
\text { the] Sydney } \\
\text { [Olympics] was like } \\
\text { taking a kid to the } \\
\text { amusement park.' }\end{array}$ \\
\hline $\begin{array}{c}\text {...results must be } \\
\text { produced at all } \\
\text { cost for coaches so } \\
\text { that they can } \\
\text { prove their } \\
\text { existence.' }\end{array}$ & $\begin{array}{c}\text { To offer } \\
\text { alternatives and } \\
\text { not to let go of } \\
\text { one's hands when } \\
\text { they quit.' }\end{array}$ & $\begin{array}{c}\text { Everyone loves } \\
\text { athletes. Especially } \\
\text { if you are } \\
\text { successful. In life, } \\
\text { you can never } \\
\text { normally do } \\
\text { something that } \\
\text { everyone } \\
\text { unconditionally } \\
\text { accepts and loves.' }\end{array}$ & $\begin{array}{l}\text { I can understand } \\
\text { the people who - it } \\
\text { will sound rude - } \\
\text { jump out the } \\
\text { window to finish } \\
\text { their participation } \\
\text { in athletics or any } \\
\text { sport.' }\end{array}$ & $\begin{array}{c}\text { After retirement, it } \\
\text { was complicated } \\
\text { for me, and it was } \\
\text { a severe problem } \\
\text { that time was } \\
\text { running out of my } \\
\text { hands, days and } \\
\text { hours, deadlines of } \\
\text { all kinds.' }\end{array}$ & $\begin{array}{c}\text { Little ones should } \\
\text { be playful. This is } \\
\text { the biggest } \\
\text { mistake in relation } \\
\text { to performance } \\
\text { constraints.' }\end{array}$ \\
\hline $\begin{array}{c}\text {...he did not burn } \\
\text { me out in the drive } \\
\text { to be successful; I } \\
\text { was systematically } \\
\text { built up to be } \\
\text { good.' }\end{array}$ & $\begin{array}{l}\text { 'Only the very } \\
\text { crazy stay there for } \\
\text { that minimal } \\
\text { amount of money, } \\
\text { doing it with love.' }\end{array}$ & $\begin{array}{l}\text { 'I went around the } \\
\text { world because of } \\
\text { my running and } \\
\text { jumping.' }\end{array}$ & $\begin{array}{c}\text { It was a space: a } \\
\text { vacuum and I felt } \\
\text { that I couldn't find } \\
\text { my place in my age } \\
\text { group.' }\end{array}$ & $\begin{array}{l}\text { I think the most } \\
\text { serious problem is } \\
\text { that an athlete } \\
\text { counts as long as } \\
\text { he/she is active.' }\end{array}$ & $\begin{array}{c}\text {...hold hands for a } \\
\text { few years and be } \\
\text { by her side as she } \\
\text { becomes } \\
\text { independent and } \\
\text { switches over to } \\
\text { everyday life.' }\end{array}$ \\
\hline
\end{tabular}

Source: own compilation

The indicative identity of athletes was constructed within a performance-based narrative plot. By exploring the identity-construction aspects of elite athletes in the re-readings and rearrangements of the text, stories emerged around three unfolding themes: the (a) "central role of coaching" during the careers of elite athletes; elite sport reflected as a (b) "protective cover"; and (c) "social connectedness" related to identity development (Figure 2).
The coaches' role emerged as vital in shaping the athlete's identity and creating the chance for an individually harmonious career: "I think the most serious problem is that an athlete counts as long as they are active. While an athlete is in this phase of their life, they should be prepared for the next period." A lack of the elements of long-term planning, a human-centered approach, and a life-long program may be components of an elite sport system, and a missing part of the individual athlete's 
personal needs, and have potentially negative effects on individual sustainability:

...results must be produced at all costs for coaches, so that they can prove their worth, and, as a result, a child can be burned out or unmotivated by the age of 15 . Little ones should be playful. This is the biggest mistake in relation to performance constraints.

b. "Protective cover": The role of contradictions, such as the comparison of the internal / external world and active / formerly active athletes, is essential in identity construction. "Everyone loves athletes. Especially if you are successful. In life, you can never normally do something that everyone unconditionally accepts and loves." An individual's identity can consist of various dimensions, while the existence of a "protective cover" is identified as a dominant lens through which "the outside world" is viewed. Sport is like a small world surrounded by a protective sheath that separates and protects athletes, yet making it extremely difficult to quit. A "closed world" that "itself is dirty, but still simpler, cleaner (!) and not as infected as the outside world." Age as a sub-theme also forms the basis of continuous comparison in relation to social status, becoming a substantial part of subjective social self-image.

I have a very tight agenda as an athlete, so my days are tied to a schedule. After retirement, it was complicated for me, and it was a severe problem that time was running out of my hands, days and hours, deadlines of all kinds. At that time, I was much more disciplined, plus at our pool it was crazy not to learn well.

Constant comparison was also related to raising awareness about what sport ("worldview" sub-theme) could give athletes in return. A "black hole" or "vacuum" may arise after emerging from under the protective cover of a life in sports. Athletes who can restructure and preserve their identities prior to finishing their athletic careers might be better able to cope with such losses. Accordingly, restructuring and preserving their identities prior to finishing their athletic careers might help them to cope with the experience of loss:

I can understand people who - this will sound rude jump out of the window to finish their participation in athletics or any sport. Well, it is a very, very terrible feeling. I have not gotten that far, thank God, but maybe because I am a tougher breed. But it has also occurred to me, I've thought: 'what the hell I am looking for in this world? I am not good at anything!' And from this point on, you feel useless, there is none of the confirmation you get from sport, and you cannot find it anywhere else, because to find it... you have worked $150 \%$ so far, and now there is a world in which every normal person who has been with you for 15 years has already taken these steps.
Here, security is considered key in terms of to what extent it is available to athletes. Personal security comes under threat during transition periods (starting and finishing a career, turning professional etc.) so a systematic approach that can protect oneself becomes essential.

Continuing in education, thereby increasing the chance of developing a dual career, was an expectation of parents which later became standard at sports clubs, but was not part of long-term planning:

It was the expectation of the [trainers at the] swimming pool that educational studies would continue. They knew that a lot of parents would take their children out if they did not learn well, so it was in the pool's interest that they studied. And the two don't rule each other out.

c. "Social connectedness": This is represented by the motif of a child and can be found in all three stakeholders (athlete, parent, coach). Two of the interviewees work as coaches, all of them have children, and all made statements not only about their athletic- but also their coaching and parental identity.

A positive personality can be acquired from doing sport and they [athletes] can carry these [this latter attitude] with them throughout their lives and it will be useful everywhere. But I am not going to force my children to pursue sport, like my parents did not want me to be a top athlete. I do not want to obstruct them either, because I know you can play a positive role in society through sport.

Principles that emerged included "never give up," "tomorrow will be better," and "start at the bottom."

I think the veteran World Championships show how much power they [athletes] have. If you use this [power] skilfully and well, you can pass on things that you may not have known about before. Certain values that a person acquires when he or she becomes a role model.

As a trainer, playfulness is emphasized as a focal point of identity construction, but as a retired, successful elite athlete and parent cognitive dissonance appears: the foremost desire is for children not to choose the path of becoming an elite athlete.

In other words, these stories indicated that very few resources were available for bridging the athletic identity with a desirable future identity to manage identity construction. "I would not do anything differently. I am grateful to my mom and my family for making this decision, for persevering, and for finally accepting my decision. Although I wouldn't let my child go in that direction." The latter quote is an indication that the desired balance between short- and long-term interests (essential for individual sustainability) in Hungarian elite sport has been severed. 


\section{Discussion}

The purpose of this study was to investigate i) the identity formation of elite athletes through experiences in sport, and ii) how to facilitate the development of a harmonic, individually sustainable sporting career. While the performance narrative was referred to as the prevailing storyline available for identity construction, results revealed three higher-order themes that are critical elements of the identity construction strategy (i.e., the central role of coaching, protective cover, and social connectedness; see Figure 2). For the individuals in the present study, their collective sporting experiences were mostly positive, such that all perceived that would do the same again. However, in line with the claims of Howells and Fletcher (2015), cognitive dissonance appeared when athletes revealed that they hope that their child will not follow their path. The understanding of identity construction elements presented here (i.e., security and social connectedness) complement pre-existing work (Szathmári \& Kocsis, 2020) about the connection between sport and individual sustainability. With pressure mounting on athletes to make the most of their athletic "investment," the temptation for them to compromise their future by exploiting their bodies for short-term gain and by cheating is growing (Barker et al., 2011), so a well-balanced life based on "The Joy of Effort" is essential (Loland, 2012).

The results reported in this research also extend previous work by positioning the mental and physical health issues produced by environmental and psychological factors. (Coyle, Gorczynski \& Gibson, 2017). Elite athletes have a broadly comparable level of susceptibility to high-prevalence mental disorders (such as anxiety and depression) as the general population (Rice et al., 2016; Nicholls \& Levy, 2016; Vveinhardt, Fominiene \& Andriukaitiene, 2019). Elite sport can cause health problems: psychological and physical pressure (Levy, Polman, Nicholls \& Marchant, 2009), and a lack of long-term planning represent the focal areas that contradict the principles of sustainability. The elements described here (e.g. coaching) complement pre-existing work on the structure and function of social connections. For example, the fact that coaches functioned as externally situated helpers (Chatfield \& Hallam, 2015), and provide long-term planning and impartial advice to athletes, is consistent with Clutterbuck's (2001) conceptualization of the mentor/coach (Sandardos \& Chambers, 2019). Moreover, parent-child mutual disclosure and the sharing of emotions contributed to personal and relational growth (Brown, Webb, Robinson \& Cotgreave, 2019). Applying IPA to the interviews, we extended Rynne and Mallett's (2014) study to find that sustainable practices were present but not guaranteed in the coach-athlete relationship development. This finding in part supports the relation to sport coaching. The humanistic approach is one that is person-centred and emphasizes the empowerment of the individual in relation to achieving personal goals in ways that respect the athlete as an emotional, political, social, spiritual, and cultural being (Cassidy, Jones \& Potrac, 2004; Lyle, 2002; Potrac, Brewer, Jones, Armour \&
Hoff, 2000). Achieving sustainability and organise human activities in a sustainable manner has become a task and an objective that we as humans must achieve partly by creating structures and new ontology that move individual behaviour in the desired direction (Heikkurinen, Rinkinen, Järvensivu, Wilén \& Ruuska, 2016; Kocsis, 2018).

Congruent with this research, previous studies have reported that transition periods (especially retiring) are of particular importance in relation to athletes' careers. Practical remedies (e.g., providing proactive support) and coaching are well-acknowledged instruments for supporting athletes with the transition phase (Hallman, Breuer, Ilgner \& Rossi, 2019; Park, 2012). The concept of sustainable sport is consistent with theoretical findings: athletic identity at the time of retirement exhibits a significant relationship with coping processes, emotional and social adjustment, pre-retirement planning, and anxiety about career decision-making (Grove et al., 2008). Interestingly, it appears that retirement may play an essential role in the evolution of experiences due to the associated distancing from events (cf. Coakley, 1983).

According to the athletes, their coaches were essential points of contact during their careers. They played a significant role in maintaining the identity of athletes and the individual sustainability of the whole system. Chambers (2017) also reflects in an analysis of Australian professional sports that one of the higher-order themes related to players' mental health concerns the player-development manager relationship. The expression of this shortage has parallels in the appearance of problems at a more general social level. A lack the elements of long-term planning, a human-centred approach, and a lifelong program all harm individual sustainability.

Offer (2006) claims that real individual sustainability means finding the right balance between short-term enjoyment and long-term security. Here, security is considered vital in terms of how much it is available to the athletes. As described, sport is a "protective cover" for participants. The analysis revealed that some of the positive outcomes were indicative of illusions regarding personal growth (Howells \& Fletcher, 2015). The findings of this study also showed that a dual career is a real long-term identity-creation option, although as Stambulova, Engström, Franck, Linnér, and Lindahl (2015) state, maintaining a constant and equal focus on both sports and studies may compromise athletes' private life, health, and well-being. Educating athletes who just start their elite sport career on how to making way for the positive values they represent (Kovacs \& Doczi, 2020) and helping them access multiple dual-career role models would help them to envisage more diverse identity narratives and directives about how to steer the task of combining elite sport with education (Ronkainen, Ryba \& Selänne, 2019).

\section{Limitations}

The study applied retrospective interviews; as such, it may have been hard for participants to recall various experiences and how these influenced their overall sense of identity. 
The research is also limited because it was only feasible to prepare a single interview with each participant, which may not have been adequate in this investigation of a complex experience. The responses of the athlete participants, who were mainly male, may not reflect those of the broader sporting elite and related environment. Their inclusion may limit the generalizability of the findings; collecting additional information from other sportspeople, including a more equal gender distribution, would strengthen the knowledge base.

\section{Conclusion and directions for future research}

There is no firm hypothesis in the literature or well-grounded theory about the individual sustainability of athletes in elite sport. Therefore, this research was not intended to justify or refute theories. Rather, the exploration of the comments and experiences of the participants about different topics help to expand the main topic. As there is little information available in this field, the approach we adopted is particularly suitable: we can base our hypotheses on the experiences of those who are involved in it. Accordingly, the participants were athletes, who, through their speech created the literature for analysis. The physiognomy of the study does not require the formulation of an assumption, but it does specifically address the research questions. The main question in our research plan was the following: what aspects of identity construction influence the identities and individual sustainability of elite athletes? The study findings indicate that coaches and the athletes' supporting system should help increase athletes' individual sustainability, insofar as athletes themselves lack the related know-how. The stakeholders in elite sport should anticipate demand from athletes in relation to implementing sustainability principles and perspectives.

The analysis shows that there is cognitive dissonance regarding the identities of elite athletes. This emphasizes that coaching, the "protective cover" and "social connectedness" (in the form of life-long career planning) should play an important role in moving elite athletes' lives in a more individually sustainable direction.

\section{References}

András, K. (2003). A sport és az üzlet kapcsolata-elméleti alapok. Mühelytanulmány (34), Budapest: BKÁE Vállalatgazdaságtan Tanszék.

András, K., Havran, Zs., Kajos, A., Kozma, M., Máté, T., \& Szabó, Á. (2019). A sportgazdaságtani kutatások nemzetközi és hazai fejlődése. Vezetéstudomány, 50(12), 136-148. https://doi.org/10.14267/VEZTUD.2019.12.12

Annerstedt, C., \& Lindgren, E.-C. (2014). Caring as an important foundation in coaching for social sustainability: a case study of a successful Swedish coach in high performance sport. Reflective Practice, 15(1), 27-39.

https://doi.org/10.1080/14623943.2013.869204
Baker, J., Yardley, J., \& Côté, J. (2003). Coach Behaviors and Athlete Satisfaction in Team and Individual Sports. International Journal of Sport Psychology, 34(3), 226-239.

Barker, D. M., Barker-Ruchti, N., Gerber, M., Gerlach, E., Sattler, S., \& Pühse, U. (2011). Youths with migration backgrounds and their experiences of physical education: An examination of three cases. Sport, Education and Society, 19(2), 186-203.

https://doi.org/10.1080/13573322.2011.632627

Barker, D., Barker-Ruchti, N., Wals, A., \& Tinning, R. (2014). High performance sport and sustainability: a contradiction of terms? Reflective Practice, 15(1), 1-11. https://doi.org/10.1080/14623943.2013.868799

Barker-Ruchti, N., Rynne, S.R., Lee, J., \& Barker, D.M. (2014). Athlete learning in Olympic sport. Sports Coaching Review, 3(2), 162-178. https://doi.org/10.1080/21640629.2014.1059136

Bohó, T., Kálóczy, M., Kézsmárki, É., Kovács, Á., Mátai, B., Mikula, A., Riesz, L., \& Siegler, Sz. (2015). Sport és környezet - a tizenhat kiemelt olimpiai sportágfenntarthatósági aspektusai. Budapest: MOB Környezetvédelmi és Fenntartható Fejlődés Bizottság.

Brewer, B. W., Van Raalte, J. L., \& Linder, D. E. (1993). Athletic identity: Hercules' muscles or Achilles heel? International Journal of Sport Psychology, 24(2), 237254.

Brown, J. D. (2005). Research methods for applied linguistics. In A. Davies \& C. Elder, (Eds.), The Handbook of Applied Linguistics (pp. 476-500). Oxford, UK: Blackwell.

Brown, J. C., Webb, L. T., Robinson, M. A., \& Cotgreave, R. (2019). Athletes' retirement from elite sport: A qualitative study of parents and partners' experiences. Psychology of Sport and Exercise, 40(January), 51-60. https://doi.org/10.1016/j.psychsport.2018.09.005

Cassidy, T., Jones, R.L., \& Potrac, P. (2004). Understanding sports coaching: The social, cultural and pedagogical foundations of coaching practice. London: Routledge

Chambers, T. (2017). An interpretative phenomenological analysis of the player development manager role in Australian professional sports. Qualitative Research in Sport, 11(2), 237-254. https://doi.org/10.1080/2159676X.2017.1397540

Chatfield, S.L., Hallam, J.S. (2015). Flipping the on switch: Men who became regularly physically active during middle age. International Journal of Sport and Exercise Psychology, 14(4), 340-352. https://doi.org/10.1080/1612197X.2015.1036097

Clutterbuck, D. (2001). Everyone needs a mentor: Fostering talent at work. London: CIPD.

Coakley, J.J. (1992). Burnout Among Adolescent Athletes: A Personal Failure or Social Problem? Sociology of Sport Journal, 9(3), 271-285. https:/doi.org/10.1123/ssj.9.3.271

Coakley, J.J. (1983). Leaving Competitive Sport: Retirement or Rebirth? Quest, 35(1), 1-11. https://doi.org/10.1080/00336297.1983.10483777 
Cosh, S., LeCouteur, A., Crabb, S., \& Kettler, L. (2013). Career transitions and identity: a discursive psychological approach to exploring athlete identity in retirement and the transition back into elite sport. Qualitative Research in Sport, Exercise and Health, 5(1), 21-42, https://doi.org/10.1080/2159676X.2012.712987

Coyle, M., Gorczynski, P., \& Gibson, K. (2017). "You have to be mental to jump off a board any way": Elite divers' conceptualizations and perceptions of mental health. Psychology of Sport and Exercise, 29(March), $10-18$.

https://doi.org/10.1016/j.psychsport.2016.11.005

Crawford, E. R., LePine, J. A., \& Rich, B. L. (2010). Linking job demands and resources to employee engagement and burnout: A theoretical extension and metaanalytic test. Journal of Applied Psychology, 95(5), 834-848. https://doi.org/10.1037/a0019364

Dénes, F., \& Misovitz, T. (1994). Bevezetés a sportökonómiába. Vezetéstudomány, 25(3), 57-61.

Dingle, G., \& Mallen, C. A. (2020). Sport and education for environmental sustainability. In Dingle, G., \& Mallen, C. A. (Eds.), Sport and environmental sustainability: Research and strategic management (pp. 243-260). London: Routledge. https://doi.org/10.4324/9781003003694-13

Dohlsten, J., Barker-Ruchti, N., \& Lindgren, E.C. (2020). Sustainable elite sport: Swedish athletes' voices of sustainability in athletics. Qualitative Research in Sport, Exercise and Health. https://doi.org/10.1080/2159676X.2020.1778062

Fett, R., Bruns, K., \& Lischka-Wittmann, S. (2009). Results of a Qualitative Market Research Study Evaluating the Quality of Medical Letters. Drug Information Journal, 43(6), 697-703. https://doi. org/10.1177/009286150904300607

Fletcher, D., \& Sarkar, M. (2012). A Grounded Theory of Psychological Resilience in Olympic Champions. Psychology of Sport and Exercise, 13(5), 669-678. http://dx.doi.org/10.1016/j.psychsport.2012.04.007

Gelei, A. (2006). A szervezet interpretatív megközelítése. Vezetéstudomány, 38(1. ksz). pp. 79-97. https://doi.org/10.14267/VEZTUD.2006.ksz1.08

Grove, J. R., Lavallee, D., \& Gordon, S. (1996). Coping with retirement from sport: The influence of athletic identity. Journal of Applied Sport Psychology, 9(2), 191-203.

https://doi.org/10.1080/10413209708406481

Hallmann, K., Breuer, C., Ilgner, M., \& Rossi, L. (2019). Preparing elite athletes for the career after the career: the functions of mentoring programmes. Sport in Society, 23(7), 1217-1234

https://doi.org/10.1080/17430437.2019.1613375

Harangozó, G., Csutora, M., \& Kocsis T. (2018). How big is big enough? Sustainable Development, 26(2), 172-181. https://doi.org/10.1002/sd.1728

Heikkurinen, P., Rinkinen, J., Järvensivu, T., Wilén, K., \& Ruuska, T. (2016). Organising in the Anthropocene: an ontological outline for ecocentric theorizing. Journal of Cleaner Production, 113(Febr), 705-714.

https://doi.org/10.1016/j.jclepro.2015.12.016

Howells, K., \& Fletcher, D. (2015). Swimmers: Constructive Reality or Illusory Self-Deception? Journal of Sport and Exercise Psychology, 38(2), 173-186. https://doi.org/10.1123/jsep.2015-0159

Kassai, Sz., Pintér J., \& Rácz J. (2017). Az interpretatív fenomenológiai analízis (IPA) módszertana és gyakorlati alkalmazása. Vezetéstudomány, 48(4), 28-35. https://doi.org/10.14267/VEZTUD.2017.04.05

Kerekes, S., Marjainé, Sz. Zs., \& Kocsis, T. (2018). Sustainability, environmental economics, welfare. Budapest: Corvinus University of Budapest. http://doi.org/10.14267/cb.2018k05

Király,G., Pataki, Gy., Köves, A., \& Balázs, B. (2013). Models of (future) society: Bringing social theories back in backcasting. Futures, 51(July), 19-30. https://doi.org/10.1016/j.futures.2013.05.001

Kim, M., Kim, A. C. H., Newman, J. I., Ferris, G. R., \& Perrewé, P. L. (2019). The antecedents and consequences of positive organizational behavior: The role of psychological capital for promoting employee well-being in sport organizations. Sport Management Review, 22(1), 108-125.

http://dx.doi.org/10.1016/j.smr.2018.04.003

Kocsis, T. (2018). Finite earth, infinite ambitions: Social futuring and sustainability as seen by a social scientist. Society and Economy, 40(1), 111-142. https://doi.org/10.1556/204.2018.40.S1.6

Kovacs, A., \& Doczi, T. (2020). Elite athletes and media appearances: opportunity or obligation?, Sport in Society, 23(7), 1136-1145. https://doi.org/10.1080/17430437.2019.1599861

Lally, P. (2007). Identity and athletic retirement: A prospective study. Psychology of Sport and Exercise, 8(1), 85-99. https://doi.org/10.1016/j.psychsport.2006.03.003

Larkin, M., Eatough, V., \& Osborn, M. (2011). Interpretative phenomenological analysis and embodied, active, situated cognition. Theory and Psychology, 21(3). 318-337. https://doi.org/10.1177/0959354310377544

Lawson, H. (2005). Empowering people, facilitating community development, and contributing to sustainable development: The social work of sport, exercise, and physical education programs. Sport, Education and Society, 10(1), 135-160. https://doi.org/10.1080/1357332052000308800

Levy, A. R., Polman, R.C.J., Nicholls, A.R., \& Marchant, D.C. (2009). Sport injury rehabilitation adherence: Perspectives of recreational athletes. International Journal of Sport and Exercise Psychology, 7(2), 212229. https://doi.org/10.1080/1612197X.2009.9671901

Liegey V., Madelaine S., Ondet C., \& Veillot A. (2013). Un projet de Décroissance. Manifeste pour une Dotation Inconditionnelle d'Autonomie (DIA). Paris: Les Éditions Utopia. 
Lindsey, I. (2008). Conceptualising sustainability in sports development. Leisure Studies, 27(3), 279-294. https://doi.org/10.1080/02614360802048886

Loland, S. (2006). Olympic sport and the ideal of sustainable development. Journal of the Philosophy of Sport, 33(2), 144-156. https://doi.org/10.1080/00948705.2006.9714698

Loland, S. (2012). A Well Balanced Life Based on 'The Joy of Effort': Olympic Hype or a Meaningful Ideal? Sport, Ethics and Philosophy, 6(2), 155-165. https://doi.org/10.1080/17511321.2012.666990

Lundqvist, C. (2011). Well-being in competitive sportsThe feel-good factor? A review of conceptual considerations of well-being. International Review of Sport and Exercise Psychology, 4(2), 109-127. https://doi.org/10.1080/1750984X.2011.584067

Lyle, J. (2002). Sports coaching concepts: A framework for coaches' behaviour. London: Routledge

Miles, M.B., \& Hubermann, A.M. (1994). Qualitative Data Analysis. Newbury Park,CA.: Sage.

Mitev, A.Z. (2012). Grounded theory, a kvalitatív kutatás klasszikus mérföldköve. Vezetéstudomány, 43(1), 17-30. http://unipub.lib.uni-corvinus.hu/501/1/ vt_201201p17.pdf

Nicholls, A. R., \& Levy, A. R. (2016). The road to London 2012: The lived stressor, emotion, and coping experiences of gymnasts preparing for and competing at the world championships. International Journal of Sport and Exercise Psychology, 14(3), 255-267. https://doi.org/10.1080/1612197X.2015.1020664

Offer, A. (2006). The Challenge of Affluence: Self-Control and Well-Being in the United States and Britain since 1950. Oxford, United Kingdom: Oxford University Press.

Overbye, M. (2018). An (Un)desirable Trade of Harms? How Elite Athletes Might React to Medically Supervised 'Doping' and Their Considerations of Side-effects in This Situation. International Journal of Drug Policy, 55(May), 14-30. https://doi.org/10.1016/j.drugpo.2017.12.019.

Park, S., Lavallee, D., \& Tod, D. (2012). Athletes' career transition out of sport: a systematic review. International Review of Sport and Exercise Psychology, 6(1), 22-53. https://doi.org/10.1080/1750984X.2012.687053

Pietkiewicz, I. - Smith, J. A. (2014). A practical guide to using Interpretative Phenomenological Analysis in qualitative research psychology. Czasopismo Psychologiczne Psychological Journal, 20(1), 7-14. https://doi.org/10.14691/CPPJ.20.1.7

Potrac, P., Brewer, C., Jones, R.L., Armour, K.M., \& Hoff, J. (2000). Toward a holistic understanding of the coaching process. Quest, 52(2), 186-199. https://doi.org/10.1080/00336297.2000.10491709

Preuss, H. (2019). Event legacy framework and measurement, International Journal of Sport Policy and Politics, 11(1), 103-118. https://doi.org/ 10.1080/19406940.2018.1490336

Richardson, J., \& McKenna, S. (2020). An exploration of career sustainability in and after professional sport.
Journal of Vocational Behavior, 117(March), 103314. https://doi.org/10.1016/j.jvb.2019.06.002

Rice, S. M., Purcell, R., De Silva, S., Mawren, D., McGorry, P. D., \& Parker, A. G. (2016). The Mental Health of Elite Athletes: A Narrative Systematic Review. Sports Medicine, 46(9), 1333-1353.

https://oi.org/10.1007/s40279-016-0492-2

Ronkainen, N., Ryba, T., \& Selänne, H. (2019). "She is where I'd want to be in my career": Youth athletes' role models and their implications for career and identity construction. Psychology of Sport and Exercise, 45(Nov), 101562. https://doi.org/10.1016/j.psychsport.2019.101562

Rubin, H. J., \& Rubin, I. S. (2012). Qualitative Interviewing: The Art of Hearing Data. Thousand Oaks, London, New York: Sage.

Ryan, C. (2018). Navigating the athlete role: identity construction within New Zealand's elite sport environment. Qualitative Research in Sport, Exercise and Health, 10(3), 306-317. https://doi.org/10.1080/2159676X.2017.1399923

Rynne, B. S., \& Mallett, J. C. (2014). Coaches' learning and sustainability in high performance sport. Reflective Practice, 15(1), 12-26. https://doi.org/10.1080/14623943.2013.868798

Sandardos, S.S., \& Chambers, T. P. (2019). "It's not about sport, it's about you": An interpretative phenomenological analysis of mentoring elite athletes. Psychology of Sport and Exercise, 43(July), 144-154. https://doi.org/10.1016/j.psychsport.2019.02.003

Schubring, A., \& Thiel, A. (2014). Growth problems in youth elite sports. Social conditions, athletes' experiences and sustainability consequences. Reflective Practice, 15(1), 78-91. https://doi.org/10.1080/14623943.2013.868793

Smith, J. A., Flowers, P., \& Larkin M. (2009). Interpretative Phenomenological Analysis. London: Sage.

Smith, J. A. (2011). Evaluating the contribution of interpretative phenomenological analysis. Health Psychology Review, 5(1), 9-27.

https://doi.org/10.1080/17437199.2010.510659

Somogyi, K., Birtalan, I., Einspach-Tisza, K., Jantek, Gy., Kassai, Sz., Karsai, S., Sebestyén, E., Dúll, A., \& Rácz, J. (2018). Mi történik egy kvalitatív módszertan doktori szemináriumon? A GT- és IPA-elemzés menete. Alkalmazott Pszichológia, 18(2), 105-127. https://doi.org/10.17627/ALKPSZICH.2018.2.105

Stambulova, N., Engström, C., Franck, A., Linnér, L., \& Lindahl, K. (2015). Searching for an optimal balance: Dual career experiences of Swedish adolescent athletes. Psychology of Sport and Exercise, 21(Nov), 4-14. https://doi.org/10.1016/j.psychsport.2014.08.009

Szathmári, A. (2017). Building sustainability in sport: a clear offside or chance for a „slow" rebirth? Vezetéstudomány, 48(11), 33-40. https://doi.org/10.14267/VEZTUD.2017.11.04 
Szathmári, A., \& Kocsis, T. (2020). Who cares about Gladiators? An elite-sport-based concept of Sustainable Sport. Sport in Society. https://doi.org/10.1080/17430437.2020.1832470

Thelwell, R. C., Weston, N. J. V., \& Greenless, I. A. (2007). Batting on a sticky wicket: Identifying sources of stress and associated coping strategies for professional cricket batsmen. Psychology of Sport and Exer- cise, 8(2), 219-232.

https://doi.org/10.1016/j.psychsport.2006.04.002

Vveinhardt, J., Fominiene, V.B., \& Andriukaitiene, R. (2019). "Omerta" in Organized Sport: Bullying and Harassment as Determinants of Threats of Social Sustainability at the Individual Level. Sustainability, 11(9), 2474.

https://doi.org/10.3390/su11092474 